\title{
Personal Finance Management among Gender
}

\section{Sanie Doda, PhD Candidate}

Lecturer, Universiti "Aleksander Moisiu" Durres, Albania

E-mail: sanijedoda@yahoo.com

\section{Doi:10.5901/mjss.2014.v5n6p47}

\section{Abstract}

Finance is the primary mechanism to developing a country. The gender dimension presents a service to developing finance mechanisms and its results consistent with the general development purposes, including the two main components, the female one and the male one. The main clauses which are part of a potential in all groups of society should definitely include both gender because these two, participate and benefit from the economic development. The new research in macroeconomics shows that in many cases, economy development politics are formulated without gender consciousness. This not only strains the situation but makes it difficult to achieve macroeconomics purposes. There are cases when the growth is achieved at the expense of gender equality. The proverb "Men come from Mars and women come from Venus" might be true especially when it comes to their views in finance. The way a man and a woman view the decision making in finance management and the connection they have with the money, shows that the two parties come from different universes.

Keywords: Personal finance; Budgetary planning; Investment among gender.

\section{Contribution and Benefits of the Study}

The contribution of the study includes a conceptual model that identifies factors influencing the financial decisions between the sexes, focusing on two key questions:

- How does gender affect financial decision making?

- How does marital status affect the financial decision?

The purpose of this study is to show how the sexes act and think in decision-making and use of personal finance. The study is based on theory and research on various grounds:

First, it has to do with literature review on the topic.

Secondly, it is based on different indicators of socio-economic and cultural factors between the sexes.

\section{Finance Management among Gender}

In the recent years, there has been a high interest in researches showing who between women and men manage personal finances better (Kroska, A. 2008). There are stereotypes (Bartkus, K.R., Peterson M.F. and Bellenger, D.N. 1989) based on the unavoidable fact that women spend more in family, while men care about long term investments. According to personal finance experts, women tend to be more oriented to put details on their money. On the other hand, men tend to be reserved about spending money in small things but they are obsessed with bigger finance views such as a car, a house, a land or stocks. However, financial success as for women, as for men depends on the individual, not on the gender.

Even if men and women have a few differences on their outfit, they still have unique gender differences on addressing the wallet issue because of social circumstances and differences. Even though these differences are not uniform, they do favor one gender over the other; making the challenge deeper in many women by limiting their profits, by making their lives more expensive and complicating their money management.

To avoid being left aside, there are studies by resource materials such as surveys conducted in Albania and in the State of Connecticut which bring us a more complete framework of the personal finance development among the two countries. 
Figure 1: The type of personality of the interviewees/ respondents in Albania

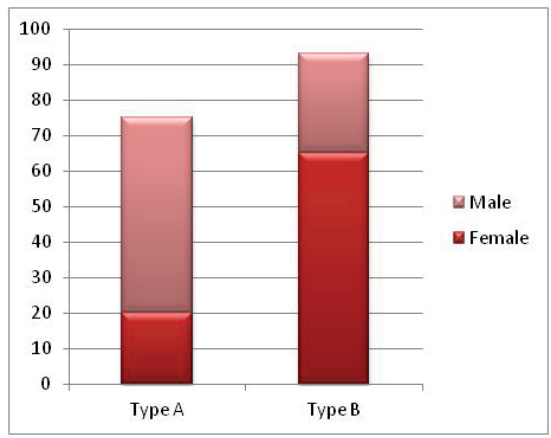

Figure 2: Type Personality of U.S. respondents in Connecticut

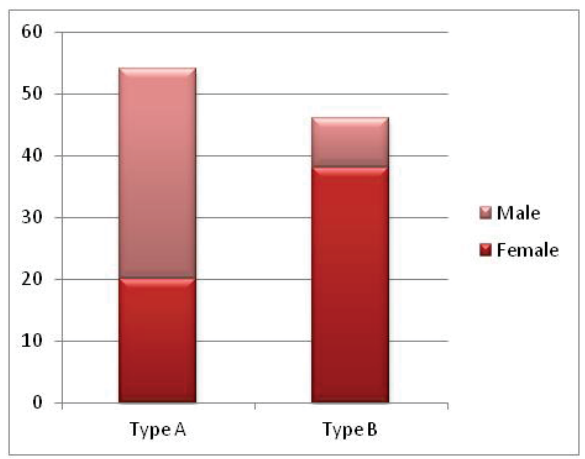

As it can be noticed from the two graphs above, most women carry a Type A personality, while most men carry a type B personality. The same conclusion applies to both countries. This clearly shows that women are more "risk adverse" or opposed to risks.

Dealing with this challenge is the next step of the women in the finance area revolution, which begin with the female as part of eternal reca in every part of her job. Females today can be managers and leaders just like men can, but now we have reached a point where is known that there can be successful business women, by embracing so rivalries in professional success.

Subjective differences (in individual tolerance to financial risk) between different family structures, age, incomes of each, cooperate with the main effects of family structure (marriage status and children) and affect the financial decisions (Wilhelmson et. al., 2005).

Women investments often take after the family model they live in, so females believe that they can make smart decisions with their money. Females are often more sensitive about their image than men are, therefore, they spend more on it. They spend a lot of money on outfits, shoes or bags; on remodeling the house, including home equipments.

Women are not known for taking risks, that is why their investments are made in areas they know and they can predict. The point of differences in money management between a woman and a man is that women object taking risks more than men, when talking about financial decision making Duda et. Al 2008). Men and women live in different planets and act in different financial orbits. A lot of studies have showed that attitudes between a man and a woman related with investments and saving are opposite (Bajtelsmit \& VanDerhei, 1997; Bajtelsmit, Bernasek, \& Jianakoplos, 1996; Embrey \& Fox, 1997; Hinz, McCarthy, \& Turner, 1997; Yuh \& Hanna, 1997).

\subsection{Gainings}

The biggest gender difference is not a surprise, studies, such as the one published from the State Office of General Contability in USA, in 2003, titled "Women's Gainings" show that women are paid in a lower norm and gain less than men 
do, so they have lower profits from social securities and accumulations of retirement.

Because the duty of taking care for special categories (children, aged parents and/or a large family) traditionally affects mostly women, and so they have less time to work. Only women without children mostly are seen as available of taking care for an elderly parent.

These responsibility 'force' women choosing jobs that do not require traveling a lot or working with long hours and also jobs that give you day off when you require, which affect building a career. Even thought men participate the common responsibilities, women are more careful, taking less time out, less time to work or less opportunity to develop a certain job relationship as a tele-operator, where they can work from home.

\section{Investment Management among Gender}

Why men are more willing to take risks when it is about investing? Views have come to a conclusion where men take bigger risks than women do. For example, studies show that men divide a big part of their investments wallet in actions rather than in obligations. About investments, a bigger risk taken means a bigger profit.

Women compared to men, tend to invest equally with them, but the important part of their spending, goes to physical appearance and safety.

Women have a high living cost:

\subsection{Physical appearance}

Attractive persons tend to have a career progress in the world of business. Women care a lot about their appearance and spend mostly in outfits, cosmetics, personal care and in extreme cases: plastic surgery.

\subsection{Safety}

Females by nature tend to risk especially as mothers. Women may spend more in gifts, vacations, friends, family and coworkers. Also, women are so willing to make gifts, the have this new tendency called 'charity organizations' which say that women are the bigger donators. This has improved the status of women and has increased the level of safety in societies.

Even though married women are traditionally responsible of managing, still their husbands take most of financial decisions about things they buy and investments. Women have an equal tendency to invest and to strictly follow the investments advice. They can accumulate appropriate equipments for a long life and a higher quality of health care. To avoid nonconformity between family finance managing, through gender, it is seen as necessary: an open communication between partners because it is a critical factor for financial harmony (Duda, F. R., dhe Gennaro, M., Schubert, R. 2006).

A spouse must have the same intentions as the other so we can have a successful communication. The only way for this to happen is if men and women communicate freely their points of view and listen to each other. The results of the table underneath show the biggest contrasts between a man and a women according to their financial situations.

Table 3.2: Financial plan among men and women

\begin{tabular}{|l|l|c|}
\hline \multicolumn{1}{|c|}{ Financial plan } & Men & Women \\
\hline A very careful financial planing & $39 \%$ & $49 \%$ \\
\hline No changes in their financial plan & $51 \%$ & $38 \%$ \\
\hline Worried about their spendings & $54 \%$ & $69 \%$ \\
\hline The amount of responsibility they trasmit to the other partner & $53 \%$ & $17 \%$ \\
\hline Sharing responsibilities with their partner & $45 \%$ & $73 \%$ \\
\hline Sattisfaction deriving from decision making & $53 \%$ & $45 \%$ \\
\hline Changes their children bring to the financial plan & $55 \%$ & $57 \%$ \\
\hline
\end{tabular}

These results show an inequality between couples about personal finance management. In all these cases women are 8$9 \%$ more worried than men.

Parents concern about the raise of their children and think of a tough financial period. It is very important for a parent to talk with his children often about money, starting in a young age. Parents must help their children to build their own budget by talking about the essentials of finance such as: saving, spending and gaining. Following this path with 
children since the beginning of their life, children will be more likely to practice these values while growing up. It is not important the amount of money a family has, the important part is that family must financially educate their children, providing them this way in the future, a financial success.

\section{Spending Dilemma}

Women in general are responsible of food, house articles and articles for children. They seem to spend a lot of money because they spend to provide a normal living. Men do not need these everyday spending because those are made by his wife, men only take care for the progress. In reality, men do damage as much as women do. Men spend on big things, such as a house, a car, a brand new TV set, etc. But men and women are both responsible for their financial status. So they both need commitment as a part of their solution.

Even though spending habits are different, a simple budget can be the solution for a financial success and happiness. A budget is necessary to make sure that both men and women are working in the same direction for a common purpose. For a lot of couples a counselor or a financier is needed to take care of building a budget, financial discussions including the value for investments.

If they cooperate with a financial counselor they will have benefits in the future. Husbands must order they bills according to their dates and after decide if they have enough money to pay the bills and to make routine purchases. They might need another source to make the difference. One of the partners might need to save money for: books, subscription in a magazine, joining a gym etc. After the have cut these spending, they can rebuilt their budget basing in long term purposes counting what they have to save every month. What is left from the gaining can be divided with each person of the family. The women then must know exactly the amount of money left for her every month and then, husbands can decide how to spend their money. After the budget has been put in action, they can cheer its benefits and feel peaceful knowing they control their finances.

Income analysis by gender implicates us for a request of a connection between gender and personal finance.

A constant question after the crises is: how things would have been different if women would have worked as leaders in the finance sector. Tradesmen tend to be young, aggressive. Cawood. F (2005) embraces this thought "Bank crises was caused by allowing what any other society wouldn't, allowing young men behaving in an irregular way."He says "Whoever studied neuro-biology would have predicted the disaster."

However, this argument is one of the many others, that the financial industry has a lot of different jobs for different personalities. Dealers are and always have been young and aggressive. The absence of order in dealers was not the issue but there was a need of a better observation in managing. In the entire chain there should be head individual. Especially this is true because the highest leader must have the maturity and the right experience.

The expose of powerful banks should have come with a plan of managing the risk and not with an excessive trust on dealers. The question is not about having more men or women. A helpful question is what would happen if banks would have women in key roles as leaders and board members; of course, this question dives you in deep thoughts.

Women with children work in short hours and are chosen in jobs less than women without children. Have a child has a lower affect on women's gaining. A luxury life comes only if the husband gains a lot or benefits from a business of he's.

Also, there is evidence that the payment issue can be explained with the fact that women are less likely to negotiate their payment by asking and promoting more. Making such demands comes with the alert to take a high risk. One of the biggest problems of women is that they work really hard and obtain a lot of work.

We cannot blame women if they want to spend time with their children. Finance as a profession is still dominated by men and it requires sacrifice, courage and a full time commitment. Men, unlike women, relate with each other to avoid and fight stress. This might lead to a confusion and a perception that colleague women are unstable and often "emotional". Men too try to take hard decisions supporting their coworkers.

Even if the number of women that introduce into a job is increasing, the years of economics booms left behind prejudice and the payment gap. The transmitted message after all this is that women are not strategy planners when it comes to money.

Knowing the general statement about female finance, many believe that woman use shopping as a cure to add satisfaction in their fantasies, while waiting for the charmed prince that is needed to pay all their debits. In real life we use the notion that what is pretty and feminine is also dangerous in the financial aspect. However, this notion is no longer accepted.

Few is said or written about poor women, which have embraced debit problems. Women are more sensitive than men when it comes to poverty and debits. 
Women debits can be caused by conflicts and psychological issues. For all types of women, their finances are less stable compared to their husbands and are more likely to be affected by changes such as having a baby or divorce. In a family, men control long term financial decisions while women are in charge of everyday spending. It has to know if women desire more power, but many women step back from financial planning because of their husbands.

Because of responsibilities in family and lower gaining, women have less chance to built financial security; they often stop saving when becoming mothers and then find themselves in difficult situations to start again. Men can fight for their retirement fund until their 40s or 50s, but women find themselves taking care of their elder relatives and so they are not able to rebuilt their career, their gaining; therefore their savings are low. In a darkly statistic, the British Society of Insurers, says that about 36\% of women that work, do not save for retirement (Cawood F, 2005).

Finance is just like one of those recent taboos, many women find themselves in taught situations and as a consequence they find it difficult to take financial initiatives to get out of the crisis. However, women must not stay in darkness when it comes to money. Women, more then men, must be financially aware to overcome inequalities and to get along with the fact that work will not always be stable.

If they have debts, they must use their financial power to change their lives, by spending and investing. Loan crisis showed that men do not own better mystic power. Therefore, women must value more themselves by valuing their finance situation.

\section{Summary and Conclusions}

Money is an instrument, with which we support our values and priorities, but it is important for individuals to have enough money to live a life of quality and to obtain financial stability.

Women see money as in instrument to create a life style; they don't consider themselves as genies in finance.

Men see money as an instrument to gain value.

One of the essentials factors that defines the health of family finances is an open communication among partners. Partners must be able to communicate freely about their everyday spending and especially about expensive spending.

There are some meaningful differences in financial decision making based on gender, age and the level of gaining. Gender differences affect the definition of financial planning and the definition of financial success.

A good investment of an individual savings might give a profitable return in the future. Individuals must do a prior investigate to decide where will they invest, considering their gaining and the risk. They can invest in an asset, in a business or even in the stock market.

There exist differences in money management among women and men; women are more likely to take risks in finance decision making than men.

Women in Albania must be more conscious and financially independent to overcome inequalities. They must be able to deal with finance with or without a man in their life.

Married individuals and those with children are more opposed to risk than single individuals are.

\section{References}

Bartkus, K.R., Peterson M.F. and Bellenger, D.N. 1989, Type A Behavior, Experience, and Salesperson Performance. Journal of Personal Selling and Sales Management, Vol. 9, Summer, faqe. 11-18.

Bajtelsmit, V. L., \& Bernasek, A. (1996). Why do women invest differently than men? Financial Counseling and Planning, 7, 1-10. Bajtelsmit, V. L., Bernasek, A., \& Jianakopolos, N. A. (1996). Gender effects in pension investment allocation decisions. Center for Pension and Retirement Research, 145-156.

Bajtelsmit, V. L., \& VanDerhei, J. A. (1997). Risk aversion and retirement income adequacy. In M. S. Gordon, O. S. Mitchell, \& M. M. Twinney (Eds.), Positioning pensions for the twenty-first century. Philadelphia: University of Pennsylvania Press

Cawood W. F and Associates Inc, Personal Finance for Seniour, FC\&A, United States of America 2005, f. 100-300

Duda, F. R., de Gennaro, M., Schubert, R. 2006. Gender, Financial Risk, and Probability Weights. Theory and Decision. Vol. 60, Iss. 2-3; f. $260-283$.

Kroska, A. 2008. Examining Husband-Wife Differences in the Meaning of Family Financial Support. Sociological Perspectives. Vol. 51, Iss. 1, faqe. 63-91.

Wilhelmson, K., Andersson, A., Waern, M. and Allebeck, P. 2005. Elderly people's perspectives on quality of life. Ageing and Society. Vol. 25, Part 4, f. 585-601. 
